\title{
Eastern Prickly Pear (Opuntia humifusa Raf.) Power Enhanced the Quality of Korean Traditional Wine, Takju
}

\section{Young-Joon Choi'1, Sanjeev Kumar Dhungana², II-Doo Kim³}

\author{
${ }^{1}$ Food Beverage and Culinary Arts, Daegu Technical University, Daegu 42734, Korea \\ ${ }^{2}$ School of Applied Biosciences, Kyungpook National University, Daegu 41566, Korea \\ ${ }^{3}$ International Institute of Research \& Development, Kyungpook National University, Daegu 41566, Korea
}

\begin{abstract}
Takju, also known as makgeolli, is a famous traditional alcoholic beverage in Korea. Various studies on the effect of raw materials on the quality of takju have been carried out. This study aimed to investigate the influence of Opuntia humifusa powder on the quality of takju. Chemical characteristics, color value, antioxidant potential as well as sensory characteristics were considered for the quality evaluation. Addition of the powder improved the functional as well as organoleptic properties of takju. The optimum proportion of $O$. humifusa powder to be added for having better impact was $0.5 \%(\mathrm{w} / \mathrm{v})$. Results of this study suggested that $O$. humifusa could enhance the antioxidant potential as well as overall acceptance of Korean traditional rice wine, takju.
\end{abstract}

Keywords: antioxidant potential, Korean traditional wine, Opuntia humifusa, overall acceptance

\section{Introduction}

Takju, also known as Makgeolli, is a traditional alcoholic beverage with an alcohol concentration of 6-8\%, a characteristic fragrance with a slightly acidic character, and a sweet taste. It is a turbid wine prepared from cereals, mostly glutinous rice, and Nuruk, a fermentation starter, containing yeast and several types of fungi. It is a famous Korean traditional rice wine. Majority of native Koreans as well as foreign visitors to Korea enjoy drinking Takju. It is rich in protein and carbohydrates and also possesses a small amount of organic compounds. Beneficial health effect of this wine has received attention among consumers and researchers. However, due to a lack of unique characteristics and inferior acceptability, Takju has received an attention by food scientists to improve the quality so that its popularity could be increased. Various kinds of cocktail Takju have been developed and studies on the microbial activities, functional characteristics, utilization of raw materials, manufacture processes, extension of shelf life, and more have been carried out (Lee et al., 2002a; Han et al., 1997; Song and Park, 2003; Kim et al., 2004; Cho et al., 2010).

In order to improve the overall quality of takju, various raw materials and additives, including dandelion (Kim et al., 2000), chamomile (Lee et al., 2002b), acasia (Seo et al., 2002), and Paecilomyces japonica (Lee et al., 2002c) blueberry (Kim et al., 2015), banana (Kim et al., 2013a), mulberry (Kim et al., 2013b), Laminaria japonica (Choi et al., 2014), have been added. The quality of traditional wine and liquor has gradually improved, resulting in increased sales in recent years; however, problems still exist.

Different active substances such as polyphenols, polysaccharides, and polysaccharide-peptide complexes have been isolated from takju (Lee et al., 1996; Park and Lee, 2002). These active substances found in takju show various chemical characteristics and biological effects, including antioxidant and immunomodulating activities. Bae et al. (2010) mentioned that some takju samples possessed significantly high total polyphenol contents compared to white wine.

Opuntia humifusa (Raf.), commonly known as eastern prickly pear (EPP) is a kind of cactus, contains good radical scavenging and antiinflammatory activity (Han et al., 2007). EPP also lowered the blood glucose and cholesterol levels in streptozotocin-induced diabetic rats (Hahm et al., 2011). In addition, EPP showed anti-cancer effect by inhibiting the growth of MCF-7 Human Breast Cancer Cells (Yoon et al., 2009) and U87MG Human Glioblastoma Cells (Hahm et al., 2010). EPP has also been used in cookies (Han et al., 2007). Considering

This article is published under the terms of the Creative Commons Attribution License 4.0

Author(s) retain the copyright of this article. Publication rights with Alkhaer Publications.

Published at: http://www.ijsciences.com/pub/issue/2018-07/

DOI: 10.18483/ijSci.1750; Online ISSN: 2305-3925; Print ISSN: 2410-4477 
the functional and medicinal values of EPP and effect of raw material on wine quality the objective of this study was to investigate the quality characteristics of traditional Korean rice wine, takju, prepared with EPP.

\section{Materials and Methods}

Chemicals and materials

Folin-Ciocalteu phenol reagent and DPPH were purchased from Sigma-Aldrich (St. Louis, MO, USA). All other chemicals and reagents used were of analytical grade. EPP [Opuntia humifusa (Raf.)] powder was obtained from a local market in Daegu, Korea.

\section{Preaparation of takju samples}

Typically, Korean traditional rice wine, takju is made of steamed rice with yeast and water fermented for about $6 \mathrm{~d}$. Takju is prepared by 2-step fermentation of steamed rice without distillation. A mixture of rice koji, a commercially available steamed rice $(2 \mathrm{~kg})$, yeast $(2.5 \mathrm{~g})$ and water $(3 \mathrm{~L})$ fermented at $25^{\circ} \mathrm{C}$ for 1 d. In the second step, mixture of steamed rice $(8 \mathrm{~kg})$, nuruk $(200 \mathrm{~g})$, water $(12 \mathrm{~L})$, and different proportions of EPP powder was fermented at $25^{\circ} \mathrm{C}$ for $5 \mathrm{~d}$. Addition of various proportions of additives (blueberry powder and black rice powder) does influence the physicochemical properties of takju differently. Different varieties of takju prepared with various proportion of EPP were named as Control: Ordinary takju containing no added EPP, OH-A: takju containing $0.75 \mathrm{~g}$ of EPP in $750 \mathrm{~mL}$ of raw takju, OH-B: takju containing $3.75 \mathrm{~g}$ of EPP in 750 $\mathrm{mL}$ of raw takju, and $\mathrm{OH}-\mathrm{C}$ : takju containing $7.5 \mathrm{~g}$ of EPP in $750 \mathrm{~mL}$ of raw takju. A range of additive concentrations was used for formulation of optimum proportions of Eastern prickly pear powders so that a superior quality takju could be prepared. After preparation, takju varieties were pasteurized at $85^{\circ} \mathrm{C}$ for 5 min using a sterilizer (CK-25; Hanil Co.) and were stored at $4^{\circ} \mathrm{C}$ for subsequent analyses.

\section{Physicochemical parameters}

The $\mathrm{pH}$ value of takju was measured using a $\mathrm{pH}$ Meter (Model 250; Beckman Coulter, Inc., Fullerton, CA, USA). Titratable acidity (lactic acid in $\mathrm{g} / \mathrm{L}$ ) was measured using addition of $5 \mathrm{~mL}$ of takju to $125 \mathrm{~mL}$ of deionized water, followed by titration using $0.1 \mathrm{~N}$ sodium hydroxide to an endpoint $\mathrm{pH}$ of 8.2. Alcohol concentration was determined following the method of Ough and Amerine (1988). The brix $\left({ }^{\circ} \mathrm{Bx}\right)$ value was measured following the Official Methods of the National Tax Service (2006). All the chemical measurements were replicated 3 times and mean values were reported.

\section{Color measurement}

$\mathrm{L}^{*}$ (lightness), $\mathrm{a}^{*}$ (redness, + or greenness, - ), and $\mathrm{b}^{*}$ (yellowness, + or blueness, -) values of takju samples were measured using a chroma meter (CR300; Minolta Corp., Osaka, Japan). A Minolta calibration plate (YCIE $=94.5, \quad \mathrm{XCIE}=0.3160$, YCIE $=0.330$ ) and a Hunter Lab standard plate $\left(\mathrm{L}^{*}=97.51, \mathrm{a}^{*}=-0.18, \mathrm{~b}^{*}=+1.67\right)$ were used to standardize the instrument using a D65 illuminant (Kim et al., 2013). Color values were measured directly from 3 zones of takju and mean values were calculated.

\section{Determination of the total phenol content}

The total phenol contents of takju samples were estimated according to the Folin-Ciocalteau method (Singleton et al., 1999). The undiluted FolinCiocalteau reagent $(250-\mu \mathrm{L})$ was added to takju sample $(50 \mu \mathrm{L})$. After $1 \mathrm{~min}, 750 \mu \mathrm{L}$ of $20 \%(\mathrm{w} / \mathrm{v})$ aqueous $\mathrm{Na}_{2} \mathrm{CO}_{3}$ was added to the mixture, and the volume was made up to $5.0 \mathrm{~mL}$ using distilled water. A control sample contained all the reaction reagents except the takju sample. After incubation at room temperature under dark condition for $2 \mathrm{~h}$, the absorbance value was measured at $760 \mathrm{~nm}$ using microplate spectrophotometer (Multiskan GO, Thermo Fisher Scientic, Vantaa, Finland). Gallic acid was used to prepare a calibration curve and the total phenol contents were determined as gallic acid equivalents $(\mu \mathrm{g} / \mathrm{mL}$ of takju).

\section{DPPH radical scavenging activity}

The DPPH free radical scavenging potential was determined following the methods described by Cheung et al. (2003) with some modifications. A 0.8$\mathrm{mL}$ of $0.2 \mathrm{mM}$ DPPH ethanol solution was mixed with $0.2 \mathrm{~mL}$ of a takju sample. The mixture was thoroughly mixed and left to stand for $30 \mathrm{~min}$ at room temperature under dark condition. The absorbance value was measured at $520 \mathrm{~nm}$ using microplate spectrophotometer (Multiskan GO, Thermo Fisher Scientic).

\section{Evaluation of sensory properties}

The sensory properties of takju samples was evaluated with the freshly prepared samples. The samples were rated for color, flavor, and overall acceptance using a scale: $1=$ very poor, $2=$ poor, $3=$ fair, $4=$ good, $5=$ very good. Twenty volunteer panelists (10 women and 10 men) selected from the list of graduate students of College of Agriculture and Life Sciences of Kyungpook National University, Daegu, Korea were employed for the sensory evaluation.

\section{Statistical analysis}

Data were subjected to analysis of variance (ANOVA) using SAS9.4 (SAS Institute Inc., Cary, NC, USA). Differences between means were separated using Tukey test at $\mathrm{p}<0.05$. 


\section{Results and Discussion}

General chemical characteristics of takju

The chemical composition of takju samples in terms of $\mathrm{pH}$, alcohol, titrable acidity (TA), and soluble solid (SS) are shown in Table 1. The $\mathrm{pH}$ of ordinary takju (3.90) was significantly low compared to OH-A (4.00) and $\mathrm{OH}-\mathrm{C}$ (4.02) but not different from OH-B (3.89). Although the $\mathrm{pH}$ of takju samples was significantly different, the values differed by only a small fraction.
However, the alcohol and SS contents of takju samples were not significantly altered by the addition of EPP powder. The unaltered alcohol concentration of EPP-added takju (6\%) showed restoration of one of the fundamental attributes of Korean traditional rice wine. The TA of all the EPP-added takju samples were significantly higher $(0.21-0.24)$ than the ordinary takju $(0.18 \mathrm{~g} / 100 \mathrm{~mL}$ of lactic acid). The variation in $\mathrm{pH}$ and TA of different takju might be due to the addition of EPP powder.

Table 1. pH, alcohol, titratable acidity (TA), and soluble solid (SS) content of takju samples

\begin{tabular}{lcccc}
\hline \multirow{2}{*}{ Properties } & \multicolumn{4}{c}{ Sample $^{\mathrm{l})}$} \\
\cline { 2 - 5 } $\mathrm{pH}$ & Control & OH-A & OH-B & OH-C \\
\hline Alcohol $(\%)$ & $3.90 \pm 0.05^{\mathrm{b}}$ & $4.00 \pm 0.04^{\mathrm{a}}$ & $3.89 \pm 0.17^{\mathrm{b}}$ & $4.02 \pm 0.01^{\mathrm{a}}$ \\
\hline $\mathrm{TA}^{2)}(\mathrm{g} / 100 \mathrm{~mL})$ & $6.01 \pm 0.08^{\mathrm{a}}$ & $6.00 \pm 0.07^{\mathrm{a}}$ & $6.00 \pm 0.05^{\mathrm{a}}$ & $6.00 \pm 0.03^{\mathrm{a}}$ \\
\hline $\mathrm{SS}\left({ }^{\circ} \mathrm{Bx}\right)$ & $0.18 \pm 0.02^{\mathrm{b}}$ & $0.24 \pm 0.03^{\mathrm{a}}$ & $0.22 \pm 0.02^{\mathrm{a}}$ & $0.21 \pm 0.03^{\mathrm{a}}$ \\
\hline
\end{tabular}

${ }^{1)}$ Samples are defined in preparation of takju samples (Materials and Methods).

${ }^{2)}$ As lactic acid.

${ }^{3)}$ Quoted values are means \pm SD of triplicate measurements. Values followed by different superscripts in the same column are signigicantly different $(\mathrm{p}<0.05)$.

Color value of takju

The Hunter's color value of takju samples was significantly altered with the addition of EPP (Table 2). The lightness value of EPP-added takju (9.51-16.51) was significantly lower than the ordinary takju (45.91). The redness value of takju was significantly increased $(27.20-35.12)$ by the addition of EPP compared to the ordinary takju (2.61). The yellowness value of ordinary takju (19.81) and EPP-added takju (13.91-28.12) was significantly different except for OH-B (19.88). The variations in lightness, redness, and yellowness values among blueberry takjus might be due to addition of different proportions of EPP powder.

Table 2. Hunter's color value of takju samples

\begin{tabular}{lccc}
\hline \multirow{2}{*}{ Sample } & \multicolumn{3}{c}{ Color value $^{2)}$} \\
\cline { 2 - 4 } & $\mathrm{L}^{*}$ & $\mathrm{a}^{*}$ & $\mathrm{~b}^{*}$ \\
\hline Control & $45.91 \pm 0.05^{\mathrm{a}}$ & $2.61 \pm 0.02^{\mathrm{d}}$ & $19.81 \pm 0.02^{\mathrm{b}}$ \\
\hline OH-A & $16.51 \pm 0.04^{\mathrm{b}}$ & $35.12 \pm 0.07^{\mathrm{a}}$ & $28.12 \pm 0.03^{\mathrm{a}}$ \\
\hline OH-B & $11.21 \pm 0.08^{\mathrm{c}}$ & $31.21 \pm 0.03^{\mathrm{b}}$ & $19.88 \pm 0.03^{\mathrm{b}}$ \\
\hline OH-C & $9.51 \pm 0.05^{\mathrm{d}}$ & $27.20 \pm 0.03^{\mathrm{c}}$ & $13.91 \pm 0.02^{\mathrm{c}}$ \\
\hline
\end{tabular}

${ }^{\mathrm{I}}$ Samples are defined in preparation of takju samples (Materials and Methods).

${ }^{2} \mathrm{~L}^{*}$, lightness (100, white; 0 , black); $\mathrm{a}^{*}$, redness (-, green; +, red); $\mathrm{b}^{*}$, yellowness (-, blue; + , yellow).

${ }^{3)}$ Quoted values are means \pm SD of triplicate measurements. The values followed by different superscripts in the same column are significantly different $(\mathrm{p}<0.05)$.

DPPH radical scavenging activities and total phenol contents of takju

The addition of EPP powder significantly increased the DPPH radical scavenging activities and total phenolic contents of takju compared to the ordinary takju (Table 3). The DPPH radical scavenging activities of EPP-added takju (50.31-61.30\%) were significantly higher than that of ordinary takju $(16.31 \%)$. More than three times higher DPPH radical scavenging activities in EPP-added takju might be due to higher antioxidant potential of EPP (Han et al., 2007). Similarly, total phenol content of
EPP-added takju (292.30-445.98 $\mu \mathrm{g} / \mathrm{mL})$ was significantly high compared to that of ordinary takju (77.71 $\mu \mathrm{g} / \mathrm{mL})$. Almost six times higher total phenol content was detected in $\mathrm{OH}-\mathrm{C}$ than that in ordinary takju. Such higher values of total phenols might be due to addition of EPP powder which is rich in phenolic compounds (Yoon et al., 2009). Park and Lee (2002) report that the polyphenols, flavonoids, and flavonols in takju account for its antioxidant activities. Report shows that there are multiple mechanisms involved in wine preparation, therefore, no single assay could reveal all the antioxidants 
Eastern Prickly Pear (Opuntia humifusa Raf.) Power Enhanced the Quality of Korean Traditional Wine, Takju

precisely within a mixed or complex system (Muntana and Prasong, 2010).

Table 3. DPPH radical scavenging activities and total phenol content (TPC) of takju samples

\begin{tabular}{lcc}
\hline Sample $^{1)}$ & DPPH $(\%$ Inhibition $)$ & TPC $\left(\mathrm{GAE}^{2)} \mu \mathrm{g} / \mathrm{mL}\right.$ of sample $)$ \\
\hline Control & $16.31 \pm 2.22^{\mathrm{c}}$ & $77.71 \pm 2.20^{\mathrm{d}}$ \\
\hline OH-A & $50.31 \pm 1.81^{\mathrm{b}}$ & $292.30 \pm 3.00^{\mathrm{c}}$ \\
\hline OH-B & $60.20 \pm 1.90^{\mathrm{a}}$ & $415.31 \pm 3.75^{\mathrm{b}}$ \\
\hline OH-C & $61.30 \pm 2.02^{\mathrm{a}}$ & $445.98 \pm 5.21^{\mathrm{a}}$ \\
\hline
\end{tabular}

${ }^{1)}$ Samples are defined in preparation of takju samples (Materials and Methods).

${ }^{2)}$ Gallic acid equivalents.

${ }^{3)}$ Quoted values are means \pm SD of triplicate measurements. The values followed by different superscripts in the same column are significantly different $(\mathrm{p}<0.05)$.

Sensory characteristics of takju

Sensory characteristics of takju samples, except bitterness value, were significantly affected by the addition of EPP powder (Table 4). Based on the overall acceptance, OH-B (4.32) was the most acceptable takju. The sweetness value of EPP-added takju was increased with the increased amount of EPP powder. However, the addition of EPP powder reduced the sourness value.

Table 4. Sensory characteristics of takju samples

\begin{tabular}{llccc}
\hline \multirow{2}{*}{ Sample $^{1)}$} & \multicolumn{3}{c}{ Sensory characteristics } \\
\cline { 2 - 5 } & Sweetness & Sourness & Bitterness & Overall acceptance \\
\hline Control & $2.11 \pm 0.11^{\mathrm{c}}$ & $1.81 \pm 0.02^{\mathrm{a}}$ & $1.12 \pm 0.20^{\mathrm{a}}$ & $2.31 \pm 0.21^{\mathrm{c}}$ \\
\hline OH-A & $3.00 \pm 0.25^{\mathrm{b}}$ & $1.21 \pm 0.03^{\mathrm{b}}$ & $1.05 \pm 0.31^{\mathrm{a}}$ & $3.40 \pm 0.37^{\mathrm{b}}$ \\
\hline OH-B & $3.51 \pm 0.15^{\mathrm{a}}$ & $1.14 \pm 0.30^{\mathrm{b}}$ & $1.10 \pm 0.25^{\mathrm{a}}$ & $4.32 \pm 0.05^{\mathrm{a}}$ \\
\hline OH-C & $3.61 \pm 0.21^{\mathrm{a}}$ & $1.11 \pm 0.21^{\mathrm{b}}$ & $1.00 \pm 0.21^{\mathrm{a}}$ & $3.41 \pm 0.21^{\mathrm{b}}$ \\
\hline
\end{tabular}

${ }^{1)}$ Samples are defined in preparation of takju samples (Materials and Methods).

${ }^{2}$ Quoted values are means \pm SD of triplicate experiments $(n=20)$ based on 5 point scores (1, very poor; 2 , poor; 3 , fair; 4, good; 5, very good). Values followed by different superscripts in the same column are significantly different $(\mathrm{p}<0.05)$.

In conclusion, addition of Opuntia humifusa (Raf.) powder enhanced the functional value as well as overall acceptance of Korean traditional rice wine, takju. Addition of the powder did not cause any adverse effect on the basic chemical and organoleptic properties, instead contributed to have positive impacts in takju. Based on the overall acceptance and antioxidant potentials, the optimum proportions of $O$. humifusa (Raf.) powder to be added during takju fermentation was $0.5 \%(\mathrm{w} / \mathrm{v})$. Results of this study showed that addition of optimum amount of $O$. humifusa (Raf.) could enhance the antioxidant potentiality as well as overall acceptance of Korean traditional rice wine, takju.

\section{References}

1. Bae SH, Jung EY, Kim SY, Shin KS, Suh HJ. 2003. Antioxidant and immuno-modulating activities of Korean traditional rice wine, takju. J. Food Biochem. 34: 233-248.

2. Cheung LM, Cheung PCK, Ooi VEC. 2003. Antioxidant activity and total polyphenolics of edible mushroom extracts. Food Chem. 81: 249-255.

3. Cho EK, Kim HY, Byeon HJ, Kim SW, Choi YJ. 2010. Nitrite scavenging and alcohol metabolizing activities of hot water extract from Makgeoly and its angiotensin converting enzyme inhibitory effect. J. Life Sci. 20: 768-774.
4. Choi JS, Seo HJ, Lee YR, Kwon SJ, Moon SH, Park SM, Sohn JH. 2014. Characteristics and in vitro anti-diabetic properties of the Korean rice wine, makgeolli fermented with Laminaria japonica. Prev. Nutr. Food Sci. 19: 98-107.

5. Hahm SW, Park J, Son YS. 2010. Opuntia humifusa partitioned extracts inhibit the growth of U87MG human glioblastoma cells. Plant Foods Hum. Nutr. 65: 247-252.

6. Hahm SW, Park J, Son YS. 2011. Opuntia humifusa stems lower blood glucose and cholesterol levels in streptozotocininduced diabetic rats. Nutr. Res. 31: 479-487.

7. Han EH, Lee TS, Noh BS, Lee DS. 1997. Quality characteristics of mash of Takju prepared by using different Nuruk during fermentation. Korean J. Food Sci. Technol. 29: 555-562.

8. Han IH, Lee K, Byoun KE. 2007. The antioxidant activity of Korean cactus (Opuntia humifusa) and the quality characteristics of cookies with cactus powder added. Korean J. Food Cook. Sci. 23: 443-451.

9. Kim E, Chang YH, Ko JY, Jeong Y. 2013a. Physicochemical and microbial properties of the Korean traditional rice wine, Makgeolli, supplemented with Banana during fermentation. Prev. Nutr. Food Sci. 18: 203-209.

10. Kim E, Chang YH, Ko JY, Jeong Y. 2013b. Physicochemical and microbial properties of Korean traditional rice wine, Makgeolli, supplemented with mulberry during fermentation. J. Korean Soc. Food Sci. Nutr. 42: 1682-1689.

11. Kim ID, Lee JW, Kim SJ, Cho JW, Dhungana SK, Lim YS, Shin DH. 2013. Exogenous application of natural extracts of persimmon (Diospyros kaki Thunb.) can help in maintaining 
nutritional and mineral composition of dried persimmon. Afr. J. Biotechnol. 13:2231-2239.

12. Kim JH, Lee DH, Chio SY, Lee JS. 2002. Characterization of physiological functionalities in Korean traditional liquors. Korean J. Food Sci. Technol. 34: 118-122.

13. Kim JH, Lee DH, Lee SH, Choi SY, Lee JS. 2004. Effect of Ganoderma lucidum on the quality and functionality of Korean traditional rice wine, yakju. J. Biosci. Bioeng. 97: 24-28.

14. Kim JH, Lee SH, Kim NM, Choi SY, Yoo JY, Lee JS. 2000 Manufacture and physiological functionality of Korean traditional liquors by using dandelion (Taraxacum platycarpum). Korean J. Biotechnol. Bioeng. 28: 367-371.

15. Kim MO, Kim ID, Dhungana SK, Lee JW, Shin DH. 2015. Influence of blueberry and black rice powders on quality characteristics of the Korean traditional rice wine, Takju. Food Sci. Biotechnol. 24: 439-444.

16. Lee DH, Kim JH, Kim NM, Lee JS. 2002b. Manufacture and physiological functionality of Korean traditional liquors by using chamomile (Matricaria chamomile). Korean J. Food Sci. Technol. 34: 109-113.

17. Lee DH, Kim JH, Kim NM, Pack JS, Lee JS. 2002c. Manufacture and physiological functionality of Korean traditional liquor by using Paecilomyces japonica. Korean J. Mycol. 30: 141-146.

18. Lee JS, Lee TS, Noh BS, Park SO. 1996. Quality characteristics of mash of takju prepared by different raw materials. Korean J. Food Sci. Technol. 28: 330-336.

19. Lee SS, Kim KS, Eom AH, Sung CK, Hong IP. 2002a. Production of Korean traditional rice-wines made from cultures of the single fungal isolates under laboratory conditions. Korean J. Mycol. 30: 61-65.

20. Muntana N, Prasong S. 2010. Study on total phenolic contents and their antioxidant activities of Thai white, red and black rice bran extracts. Pakistan J. Biol. Sci. 13: 170174.

21. Official Methods of the National Tax Service. 2006. National Rural Resources Development Institute. Food composition table. Rural Development Administration, Seoul, Korea. pp. 353-370.

22. Ough CS, Amerine MA. 1988. Methods for Analysis of Musts and Wines. 2nd ed. John Wiley and Sons, New York, NY, USA. pp. 80-107.

23. Park CS, Lee TS. 2002. Quality characteristics of takju prepared by wheat flour nuruks. Korean J. Food Sci. Technol. 34: 296-302.

24. Seo SB, Kim JH, Kim NM, Choi SY, Lee JS. 2002. Effect of Acasia flower on the physiological functionality of Korean traditional rice wine. Korean J. Microbiol. Biotechnol. 30: 410-414.

25. Singleton V, Orthofer R, Lamuela-Raventos R. Analysis of total phenols and other oxidation substrates and antioxidants by means of Folin-Ciocalteu reagent. Vol. 299, pp 152-178. In: Oxidants and Antioxidants. Packer L (ed). Academic Press, New York, NY, USA.

26. Song JC, Park HJ. 2003. Takju brewing using the uncooked germed brown rice at second stage mash. J. Korean Soc. Food Sci. Nutr. 32: 847-854

27. Yoon JA, Hahm SW, Park JE, Son YS. 2009. Total polyphenol and flavonoid of fruit extract of Opuntia humifusa and its inhibitory effect on the growth of MCF-7 human breast cancer cells. J. Korean Soc. Food Sci. Nutr. 38: 1679-1684. 